\title{
A Comparative Investigation of the Views of Preschool Teachers and Teacher Candidates about STEM
}

\author{
Neslihan Ültay ${ }^{1}$, Eser Ültay ${ }^{*}$ \\ ${ }^{1}$ Department of Elementary Education, Giresun University, Giresun, Turkey \\ *Corresponding Author. eserultay@gmail.com
}

\begin{abstract}
If the STEM approach appropriately addressed in early childhood education, it may provide opportunities for educators to involve children in activities appropriate to their interests and experiences. The purpose of this research is to investigate comparatively the views of preschool teachers and preschool teacher candidates about STEM. To collect data, 60 preschool teachers graduated from different universities in Turkey have different experiments and actively in the teaching profession in various schools in the years 2018 to 2019, and 65 preschool teacher candidates in the first, second, third and fourth grades in the 2018-2019 academic year at a state university in the region of the Black Sea randomly selected. To collect data, preschool teachers and teacher candidates ask to answer the questions in the Screening Form consisting of open-ended questions aimed at obtaining in-depth information about STEM education. The findings analyze in detail, and it seen that the answers of both groups can discuss under three main themes; (1) The effects of the STEM approach, (2) The applicability of the STEM approach in preschool education, and (3) The requirements of the applicability of the STEM approach in Turkish educational system. According to the findings, participants have positive views about implementing the STEM approach in their classes for the teachers and future professional lives for the teacher candidates. However, there are some limitations about implementing it arising from the infrastructure of the schools, the teachers themselves, and children's young age.
\end{abstract}

Keywords Preschool teachers, Preschool teacher candidates, STEM, Views about STEM.

\section{INTRODUCTION}

The developments in the field of knowledge, science, and technology show that there is a need for people who find creative and flexible solutions for complex problems. To accomplish growing up these people, it is needed to add some skills to the educational systems such as $21^{\text {st- }}$ century skills including critical thinking, creativity, communication, collaboration, innovation among learning and innovation skills; information and media and technology literacy skills among media and technology skills, flexibility and entrepreneurship in life and career skills (Uğraş, 2017). For students, it does not seem possible to gain $21^{\text {st }}$-century skills by the classical learning approaches. In particular, the ability to address these skills as a whole gives in the STEM approach. STEM approach is that Science, Technology, Engineering, Mathematics formed by a combination of the first letters of the area and is an approach that aims to integrate each of these areas.

Studies have shown that the STEM approach has a positive effect on both learning and attitudes towards
STEM courses. Yildırım (2016), in his analysis, reports that STEM education approach applications improve academic achievement, problem-solving, creative thinking, scientific process skills, interest, motivation, and attitude. Özkan \& Topsakal (2017) found that most of the STEM activities were found enjoyable and exciting by the students. Akgündüz \& Akpinar's study (2018), it revealed that all students liked the exercises. It seems that STEM education, especially engineering applications, such as designing, finding alternative solutions to problems, drawing sketches, and obtaining works in advance, were effective in the development of students' motivation and attitudes towards STEM applications.

The extent to which the STEM approach should incorporate into the education system is an important point discussed (Chesloff, 2013). Some opinions are it can integrate into high schools' programs, and some think it is

Received: 27 October 2019

Revised: 9 January 2020

Published: 12 March 2020 
more appropriate to start implementing at secondary or primary level; they put forward many points as reasons for the STEM approach to be unsuitable for the preschool period. Some of these are that the STEM approach is not suitable for pre-school program type, teachers not professionally prepared for this, they do not have enough confidence to make appropriate teaching STEM approach, teaching materials prepared under STEM approach is not meaningful for preschool children (Atiles, Jones, \& Anderson, 2013; Bagiati \& Evangelou, 2015; DiPerna, Lei, \& Reid, 2007).

A group advocating that the STEM approach should implement in the preschool period suggests that preschool children behave like a natural scientist (Chesloff, 2013) and that many skills that can form the basis for further learning acquires during this period (Aldemir \& Kermani, 2017). Children begin to develop

Table 1 Demographic information of teachers participating in the research

\begin{tabular}{|c|c|c|c|}
\hline Code & Gender & $\begin{array}{l}\text { Professional } \\
\text { Experience }\end{array}$ & Graduated University \\
\hline T1 & Female & $6-10$ years & Selçuk University \\
\hline $\mathrm{T} 2$ & Female & $11-15$ years & $\begin{array}{l}\text { Süleyman Demirel } \\
\text { University }\end{array}$ \\
\hline T3 & Female & $11-15$ years & Anadolu University \\
\hline T4 & Female & $1-5$ years & Ahi Evran University \\
\hline T5 & Female & $11-15$ years & Gazi University \\
\hline T6 & Female & $6-10$ years & Gazi University \\
\hline T7 & Female & $11-15$ years & Anadolu University \\
\hline T8 & Female & $11-15$ years & Marmara University \\
\hline T9 & Female & $6-10$ years & $\begin{array}{l}\text { Karadeniz Technical } \\
\text { University }\end{array}$ \\
\hline T10 & Female & $11-15$ years & Marmara University \\
\hline T11 & Female & $6-10$ years & $\begin{array}{l}\text { Ondokuz Mayis } \\
\text { University }\end{array}$ \\
\hline T12 & Female & $11-15$ years & $\begin{array}{l}\text { Ondokuz Mayıs } \\
\text { University }\end{array}$ \\
\hline T13 & Female & $6-10$ years & $\begin{array}{l}\text { Ondokuz Mayıs } \\
\text { University }\end{array}$ \\
\hline T14 & Female & $1-5$ years & Giresun University \\
\hline T15 & Female & $6-10$ years & Giresun University \\
\hline T16 & Female & $6-10$ years & $\begin{array}{l}\text { Muğla Sitk1 Koçman } \\
\text { University }\end{array}$ \\
\hline T17 & Female & $6-10$ years & Gazi University \\
\hline T18 & Female & $11-15$ years & $\begin{array}{l}\text { Karadeniz Technical } \\
\text { University }\end{array}$ \\
\hline T19 & Female & $11-15$ years & İnönü University \\
\hline T20 & Female & $1-5$ years & Artvin Çoruh University \\
\hline T21 & Female & $1-5$ years & Bülent Ecevit University \\
\hline T22 & Female & $6-10$ years & Anadolu University \\
\hline $\mathrm{T} 23$ & Female & $6-10$ years & $\begin{array}{l}\text { Ondokuz Mayis } \\
\text { University }\end{array}$ \\
\hline T24 & Female & $6-10$ years & Sinop University \\
\hline T25 & Female & $6-10$ years & Hacettepe University \\
\hline T26 & Female & $6-10$ years & Anadolu University \\
\hline T27 & Female & $11-15$ years & $\begin{array}{l}\text { Karadeniz Technical } \\
\text { University }\end{array}$ \\
\hline T28 & Female & $6-10$ years & Marmara University \\
\hline T29 & Female & $11-15$ years & $\begin{array}{l}\text { Karadeniz Technical } \\
\text { University }\end{array}$ \\
\hline T30 & Female & $1-5$ years & $\begin{array}{l}\text { Sivas Cumhuriyet } \\
\text { University }\end{array}$ \\
\hline
\end{tabular}

some feelings about numbers long before they start counting. For example, when the number of siblings asks, they can easily say two or three; they can also tell how many slices there are on the plate (Clements \& Sarama, 2000). Besides, in preschool education, children do so many activities that require them to ask questions or explore situations like a scientist. When the preschool teacher tells a story about a cat trying to descend from the tree, children ask to develop tools with given so many different materials such as blocks, wooden sticks, paper, glue, plastic bottle, etc.

Another example can be creating a house for birds for cold weather. These examples constitute a minor part of preschool education. In preschool education, teachers and

Table 1 Demographic information of teachers participating in the research continued

\begin{tabular}{|c|c|c|c|}
\hline Code & Gender & $\begin{array}{l}\text { Professional } \\
\text { Experience }\end{array}$ & Graduated University \\
\hline T31 & Female & $6-10$ years & $\begin{array}{l}\text { Karadeniz Technical } \\
\text { University }\end{array}$ \\
\hline T32 & Female & 6-10 years & Atatürk University \\
\hline T33 & Female & $11-15$ years & Atatürk University \\
\hline T34 & Female & $6-10$ years & Anadolu University \\
\hline T35 & Female & $1-5$ years & Anadolu University \\
\hline T36 & Female & $11-15$ years & $\begin{array}{l}\text { Ondokuz Mayıs } \\
\text { University }\end{array}$ \\
\hline T37 & Female & $11-15$ years & $\begin{array}{l}\text { Karadeniz Technical } \\
\text { University }\end{array}$ \\
\hline T38 & Female & $6-10$ years & $\begin{array}{l}\text { Ondokuz May1s } \\
\text { University }\end{array}$ \\
\hline T39 & Female & $1-5$ years & Firat University \\
\hline T40 & Female & $1-5$ years & Firat University \\
\hline T41 & Female & $11-15$ years & $\begin{array}{l}\text { Karadeniz Technical } \\
\text { University }\end{array}$ \\
\hline T42 & Female & $1-5$ years & $\begin{array}{l}\text { Karadeniz Technical } \\
\text { University }\end{array}$ \\
\hline T43 & Female & $1-5$ years & Cumhuriyet University \\
\hline T44 & Female & $1-5$ years & Anadolu University \\
\hline T45 & Female & $1-5$ years & $\begin{array}{l}\text { Erzincan Binali Yıldırım } \\
\text { University }\end{array}$ \\
\hline T46 & Female & 6-10 years & Gazi University \\
\hline T47 & Female & $1-5$ years & Selçuk University \\
\hline T48 & Female & $6-10$ years & Selçuk University \\
\hline T49 & Female & $6-10$ years & $\begin{array}{l}\text { Ondokuz Mayis } \\
\text { University }\end{array}$ \\
\hline T50 & Female & $1-5$ years & Pamukkale University \\
\hline T51 & Female & $6-10$ years & Anadolu University \\
\hline T52 & Female & $6-10$ years & $\begin{array}{l}\text { Karadeniz Technical } \\
\text { University }\end{array}$ \\
\hline T53 & Female & $1-5$ years & $\begin{array}{l}\text { Girne Amerikan } \\
\text { University }\end{array}$ \\
\hline T54 & Male & $1-5$ years & Giresun University \\
\hline T55 & Female & $16-20$ years & Selçuk University \\
\hline T56 & Male & $6-10$ years & $\begin{array}{l}\text { Ondokuz Mayis } \\
\text { University }\end{array}$ \\
\hline T57 & Female & $16-20$ years & $\begin{array}{l}\text { Karadeniz Technical } \\
\text { University }\end{array}$ \\
\hline T58 & Female & $\begin{array}{l}21 \text { years and } \\
\text { over }\end{array}$ & Selçuk University \\
\hline T59 & Female & $16-20$ years & Sakarya University \\
\hline T60 & Female & $16-20$ years & $\begin{array}{l}\text { Karadeniz Technical } \\
\text { University }\end{array}$ \\
\hline
\end{tabular}


children do a lot of similar activities.

Meanwhile, children ask too many questions about the activities, experiment, build something, try, etc. All these activities can count as a part of STEM activities. STEM activities can be included in preschool education by hands-on activities that help children develop an understanding of STEM and enhance their future learning (Aldemir \& Kermani, 2017).

Furthermore, there are many types of research defending the importance of quality of preschool education period (Hayes, 2007; 2008). According to Catherwood (1999), the majority of brain development and significant learning occurs in the early childhood period. Therefore, early childhood education has crucial importance regarding some critical skills' development. If the STEM approach can correct approached in early childhood education, it could offer opportunities for educators to engage children in the activities that prioritize their interests, experiences, etc. (Campbell, Speldewinde, Howitt, \& MacDonald, 2018). Based on the body of research indicated above, the purpose of this research is to investigate comparatively the views of preschool teachers and preschool teacher candidates about STEM. Because the preschool period children behave like a scientist and ask naturally too many questions about the activities and experiments and natural events, most of them can count as that activity, and the preschool teachers should have learned how to manage children and direct the process during a STEM-based activity. Therefore this research can contribute to the preschool teachers and teacher candidates.

\section{METHOD}

This study is qualitative, and a case study, which is one of the research approaches being a method of interpretive approach used. The case study method focuses on a current phenomenon, event, situation, individuals, and groups and tries to investigate in-depth and seeks an answer to the question of what is the current situation (Ekiz, 2009).

\subsection{Participants}

To collect data, 60 preschool teachers who graduated from different universities in Turkey had various experiments and were actively in the teaching profession in a different school in the years of 2018 to 2019, and 65 preschool teacher candidates in the first, second, third and fourth grades in 2018-2019 academic years at a state university in the region of the Black Sea in Turkey were randomly selected. The demographic information of these preschool teachers is presented below in Table 1.

Within the framework of research ethics, teachers participating in the interview coded as T1, T2, .., T60 and teacher candidates are coded as TC11, TC12,..., TC116, TC217, TC218, ..., TC234, TC335, ТC336, ..., TC349, TC450, TC451, ..., TC465 respectively. The subscripts in these codes represent teacher candidates' grades. According to Table 1, 58 of the teachers are women, and only two are men. It seems that the number of teachers with experience of $1-5$ years is 16 , the number of those with 6-10 years is 24 , the number of those with 11-15 years is 15 , and the number of those with 16-20 years is four. Only one teacher has 21 years of experience. When the teacher candidates examined, it seems that 57 of the 65 teacher candidates are female, and 8 of them are male. The number of teacher candidates in the first grade is 16, while the number of second grades is 18, the number of third grades is 15 , and the number of fourth grades is 16 .

\subsection{Data collection process and data analysis}

In this study, to collect data, preschool teachers and teacher candidates were asked to answer the questions in the Screening Form provided with validity and reliability to determine their knowledge level about STEM education. The most crucial source in deciding people's behaviors and understanding their opinions about something is their statements. These statements can obtain through written or oral surveys (Balc1, 2011). The questions in the questionnaires may be independent of each other or may direct to the measurement of students' attitudes towards the lesson, teacher's classroom management behaviors or learning strategies (Büyüköztürk, Çakmak, Akgün, Karadeniz, \& Demirel, 2012). It states that the tools developed to measure features such as personal characteristics, interests, attitudes can be named as inventory, questionnaire, scale, test, and screening form. (Büyüköztürk, Çakmak, Akgün, Karadeniz, \& Demirel, 2012).

In this study, the screening form uses to determine the knowledge levels of preschool teachers and teacher candidates about STEM education. That form is consisting of open-ended questions aimed at obtaining indepth information about STEM education from teachers and teacher candidates.

The screening form, which prepares to collect data, consisted of seven open-ended questions, and the critical responses determine after transcripts and reductions. These critical answers have been subjected to descriptiveinterpretive analysis and present in the findings section in the comparative tables with frequency and percentage values.

\subsection{Quality in research}

Before the data collection process started, a field education specialist and a Turkish language expert checked for clarity and comprehension validity of the questionnaire form developed by the researchers and necessary arrangements made under the opinions of the experts.

Before the data collection process started, the participants were informed by the researchers that "the data will be used for research purposes only" and that "no 
data will share with the readers of the study except some demographic information." The purpose of this briefing is to increase the credibility of the study by enabling participants to respond comfortably and sincerely during the data collection process. Besides, the data collection process carried out in the environment that the participants were accustomed to, in other words, in their workplaces, schools, or homes to increase the credibility of the study.

To increase the credibility and consistency of the study, the answers given to the screening forms by the participants tried to be described twice by making necessary reductions at different times and places and identifying the critical answers. Expert opinions ensured the validity and reliability of these stages. Also, the raw data obtained from the screening forms were processed and the necessary reductions made, and each participant checked, and their approval received; they asked whether there was a point they wanted to add or subtract, and participant control provided.

Transferability is another criterion used instead of generalization in qualitative research (Miles \& Huberman,
1994). In qualitative research, it is possible to transfer the results to similar situations rather than generalization (Yildırım \& Şimşek, 2005). In this study, the data obtained during the research process to increase the transferability is presented to the reader in the findings section without commenting on the nature of the data. In this way, the reader will be able to reach the conclusions about the research situation more clearly and get the opportunity to transfer them to the research situations that he has created. Also, the results of the researcher should support the data (Miles \& Huberman, 1994). That is indicative of the availability confirmation. In this research, the direct statements of the participants tried to be verified.

\subsection{Ethics in research}

Participants included in the study were informed about the data collected during the data collection process with the reader as tabulated in Table 1. Also, it stated that some demographic information of teachers and prospective teachers who were participants of the study would share with the reader and their consent obtained, and it said that they would not damage in any way from the research (Cohen \& Manion, 1989; Drew, Hardman, \&

Table 2 Respondents' understanding of STEM

\section{Preschool teachers (60 people) \\ Answer}

It is a program consisting of Science,

Technology, Engineering and Mathematics

- The application of mathematicsscience-technology together

- A combination of science,

$1 \quad 1.67$ mathematics, science, technology and art

An approach in which theoretical

knowledge is turned into practice

Gives children different thinking skills

Realistic, collaborative and problem-based approach

STEM approach is to create unique

products by using children's creativity with

different materials used in science

education

Students can learn how mathematics and

science are encountered in daily life, as well

as early interest in engineering

An approach that improves the individual

in every aspect and aims to harmonize with the future

Science and mathematics approach used in preschool and upper education levels

\begin{tabular}{ll}
$\boldsymbol{f}$ & $\%$ \\
\hline 34 & 56.67 \\
9 & 15.00
\end{tabular}
A

\section{Answer}

teach consisting of Science.

It is a program consisting of Science,
Technology, Engineering and Mathematics

$\begin{array}{lll}\text { - } \begin{array}{lll}\text { The application of mathematics- } \\ \text { science-technology together }\end{array} & 6 & 9.23 \\ \text { - } \quad \begin{array}{l}\text { Mathematics, Science and } \\ \begin{array}{l}\text { Engineering Program } \\ \text { The application of mathematics- } \\ \text { engineering-technology together }\end{array}\end{array} & 1 & 4.62 \\ \text { - } \quad \begin{array}{l}\text { Social, technology, engineering } \\ \text { and mathematics education model }\end{array} & 1 & 1.54 \\ \text { - } \begin{array}{l}\text { Something about increasing the } \\ \text { use of technology in education }\end{array} & 1 & 1.54\end{array}$

$\begin{array}{lll}\text { An approach in which theoretical } & 10 & 15.38\end{array}$

knowledge is turned into practice

$\begin{array}{lll}\text { Gives children different thinking skills } & 2 & 3.08\end{array}$

Realistic, collaborative and problem-based $\quad 9 \quad 13.85$ approach

$\begin{array}{lll}\text { STEM approach is to create unique } & 2 & 3.08\end{array}$

products by using children's creativity with

different materials used in science education

Students can learn how mathematics and science are encountered in daily life, as well as early interest in engineering

Mathematics weighted program

$1 \quad 1.54$

Preparing both in-school and out-of-school $1 \quad 1.54$

learning environments

Similar to simulation

I do not know

$1 \quad 1.54$

$8 \quad 12.31$ 
Table 3 Respondents' reasoning to apply STEM

\begin{tabular}{|c|c|c|c|c|c|c|c|}
\hline Preschool teachers (60 people) & $f$ & Answer & $\%$ & $\begin{array}{l}\text { Preschool teacher candidates } \\
\text { (65 people) }\end{array}$ & $f$ & $\%$ & Answer \\
\hline $\begin{array}{l}\text { A better and lasting education is } \\
\text { provided by learning by doing }\end{array}$ & 23 & Yes & 38.33 & $\begin{array}{l}\text { A better and lasting education is } \\
\text { provided by learning by doing }\end{array}$ & 18 & 27.69 & Yes \\
\hline Improves children's thinking skills & 10 & Yes & 16.67 & Improves children's thinking skills & 9 & 13.85 & Yes \\
\hline $\begin{array}{l}\text { Supports all development areas of } \\
\text { children }\end{array}$ & 7 & Yes & 11.67 & $\begin{array}{l}\text { Supports all development areas of } \\
\text { children }\end{array}$ & 12 & 18.46 & Yes \\
\hline Supports creativity & 6 & Yes & 10.00 & Supports creativity & 10 & 15.38 & Yes \\
\hline $\begin{array}{l}\text { Information will be more useful with an } \\
\text { educational approach that follows } \\
\text { technological developments }\end{array}$ & 4 & Yes & 6.67 & $\begin{array}{l}\text { Information will be more useful } \\
\text { with an educational approach that } \\
\text { follows technological } \\
\text { developments }\end{array}$ & 9 & 13.85 & Yes \\
\hline Improves problem solving skills & 5 & Yes & 8.33 & Improves problem solving skills & 6 & 9.23 & Yes \\
\hline Encourages production & 5 & Yes & 8.33 & Encourages production & 1 & 1.54 & Yes \\
\hline $\begin{array}{l}\text { Keeps the country advanced in science } \\
\text { and technology }\end{array}$ & 3 & Yes & 5.00 & $\begin{array}{l}\text { Keeps the country advanced in } \\
\text { science and technology }\end{array}$ & 1 & 1.54 & Yes \\
\hline Improves scientific process skills & 2 & Yes & 3.33 & Supports social intelligence & 2 & 3.08 & Yes \\
\hline $\begin{array}{l}\text { In fact, I realized that my activities were } \\
\text { STEM activities }\end{array}$ & 10 & Yes & 16.67 & & & & \\
\hline Develops $21^{\text {st }}$ century skills & 2 & Yes & 3.33 & & & & \\
\hline $\begin{array}{l}\text { I like to apply different educational } \\
\text { methods in my classroom }\end{array}$ & 1 & Yes & 1.67 & & & & \\
\hline $\begin{array}{l}\text { Children become interested and curious } \\
\text { about mathematics and science }\end{array}$ & 2 & Yes & 3.33 & & & & \\
\hline \multirow[t]{2}{*}{$\begin{array}{l}\text { For years, most of the applications have } \\
\text { changed names and become popular }\end{array}$} & 2 & No & 3.33 & I do not have information & 5 & 7.69 & No \\
\hline & & & & I do not want & 1 & 1.54 & No \\
\hline $\begin{array}{l}\text { Requires a lot of preliminary work and } \\
\text { research }\end{array}$ & 1 & No & 1.67 & $\begin{array}{l}\text { Requires a lot of preliminary work } \\
\text { and research }\end{array}$ & 1 & 1.54 & No \\
\hline $\begin{array}{l}\text { STEM activity with preschool students } \\
\text { become difficult }\end{array}$ & 1 & No & 1.67 & Undecided & 3 & 4.62 & No \\
\hline
\end{tabular}

Hart, 1996). Some private dialogues between the researcher and the participants during the data collection process not reflected in the research by privacy and confidentiality principles. However, within the framework of research ethics, the teachers participating in the data collection process were found to be T1, T2, T3,.., T60; teacher candidates were coded as TC11, TC12, ..., TC116, TC217, TC218, ..., TC234, TC335, TC336, ..., TC349, TC450, TC451, ..., TC465 respectively.

\section{RESULT AND DISCUSSION}

\subsection{Findings}

Preschool teachers and teacher candidates' answers to the questions asked about STEM presented in the Table 2 with frequency and percentage values.

According to Table 2, 56.67\% of the preschool teachers and $43.08 \%$ of the teacher candidates defined STEM as a program that consists of science, technology, engineering, and mathematics as well. Some of the participants defined STEM as not including some areas of
STEM. Quite a lot percentage of the preschool teachers and teacher candidates described STEM as an approach in which theoretical knowledge turned into practice. In the group of preschool teachers, no anybody does not know STEM; however, $12.31 \%$ of the teacher candidates do not know STEM

Table 3 shows that the answers to the second question of the screening form. The majority of the preschool teachers and teacher candidates have a favorable view of using the STEM approach in their classrooms. The rationale of this view is their positive opinions about STEM, such as "STEM provides a better and lasting education by learning by doing," "STEM improves children's thinking skills and supports all development areas of children and their creativity." A little percentage of the participants have a negative view of using the STEM approach in their classrooms because some of them think that the STEM approach is required a lot of preliminary work and research; some of them have no information about the STEM approach. 
Table 4 Respondents' opinions about using the STEM approach in preschool

\begin{tabular}{|c|c|c|c|c|c|}
\hline $\begin{array}{l}\text { Preschool teachers (60 people) } \\
\text { Answer }\end{array}$ & \multicolumn{5}{|c|}{ Preschool teacher candidates (65 people) } \\
\hline $\begin{array}{l}\text { Supports children's curiosity, creativity } \\
\text { and different perspectives }\end{array}$ & 17 & 28.33 & $\begin{array}{l}\text { Supports children's curiosity, creativity and } \\
\text { different perspectives }\end{array}$ & 9 & 13.85 \\
\hline Supports children's cognitive development & 16 & 26.67 & Supports children's cognitive development & 17 & 26.15 \\
\hline Enables active participation of children & 7 & 11.67 & Enables active participation of children & 2 & 3.08 \\
\hline $\begin{array}{l}\text { Concretizes learning and makes it } \\
\text { permanent }\end{array}$ & 6 & 10.00 & Concretizes learning and makes it permanent & 3 & 4.62 \\
\hline $\begin{array}{l}\text { Make children's lives will be easier in the } \\
\text { future }\end{array}$ & 5 & 8.33 & $\begin{array}{l}\text { Make children's lives will be easier in the } \\
\text { future }\end{array}$ & 4 & 6.15 \\
\hline $\begin{array}{l}\text { With this system, unique and innovative } \\
\text { products are produced }\end{array}$ & 5 & 8.33 & $\begin{array}{l}\text { With this system, unique and innovative } \\
\text { products are produced }\end{array}$ & 6 & 9.23 \\
\hline $\begin{array}{l}\text { Develops a positive attitude towards } \\
\text { mathematics, science, technology and } \\
\text { engineering }\end{array}$ & 5 & 8.33 & $\begin{array}{l}\text { Develops a positive attitude towards } \\
\text { mathematics, science, technology and } \\
\text { engineering }\end{array}$ & 3 & 4.62 \\
\hline Technology may be a bit lacking in size & 1 & 1.67 & $\begin{array}{l}\text { Keeps the country advanced in science and } \\
\text { technology }\end{array}$ & 1 & 1.54 \\
\hline \multirow[t]{4}{*}{ Makes students like school } & 1 & 1.67 & $\begin{array}{l}\text { Contributes to all development areas of the } \\
\text { child }\end{array}$ & 1 & 1.54 \\
\hline & & & I do not know about this topic & 6 & 9.23 \\
\hline & & & Not viable in preschool & 3 & 4.62 \\
\hline & & & $\begin{array}{l}\text { It may not be sufficient by itself, it can be } \\
\text { supported by other approaches }\end{array}$ & 1 & 1.54 \\
\hline
\end{tabular}

In Table 4, the answers to the applicability of the STEM approach in the preschool period given. According to the findings, $65 \%$ of the preschool teachers and $60 \%$ of the teacher candidates think that the STEM approach is viable in the preschool period. They show that the
STEM approach supports children's curiosity, creativity, different perspectives, cognitive development, etc. However, there is someone who not have information about STEM and who does not think that the approach is viable in preschool.

Table 5 Respondents' opinions about the benefits of STEM approach

\begin{tabular}{|c|c|c|c|c|c|}
\hline \multicolumn{3}{|l|}{ Preschool teachers (60 people) } & \multicolumn{3}{|l|}{ Preschool teacher candidates (65 people) } \\
\hline Answer & $f$ & $\%$ & Answer & $f$ & $\%$ \\
\hline Develops different thinking skills & 31 & 51.67 & Develops different thinking skills & 15 & 23.08 \\
\hline Supports children's cognitive development & 25 & 41.67 & Supports children's cognitive development & 23 & 35.38 \\
\hline $\begin{array}{l}\text { Provides active learning environment, they } \\
\text { learn by having fun in co-operation }\end{array}$ & 15 & 25.00 & $\begin{array}{l}\text { Provides active learning environment, they } \\
\text { learn by having fun in co-operation }\end{array}$ & 16 & 24.62 \\
\hline Increases their interest towards the course & 12 & 20.00 & Increases their interest towards the course & 4 & 6.15 \\
\hline $\begin{array}{l}\text { Enables children to grow up as researchers, } \\
\text { curious about science }\end{array}$ & 10 & 16.67 & $\begin{array}{l}\text { Enables children to grow up as } \\
\text { researchers, curious about science }\end{array}$ & 3 & 4.62 \\
\hline Allows children to have versatile information & 9 & 15.00 & $\begin{array}{l}\text { Allows children to have versatile } \\
\text { information }\end{array}$ & 16 & 24.62 \\
\hline Develops self-confidence & 7 & 11.67 & Develops self-confidence & 7 & 10.77 \\
\hline Contributes to permanent learning & 6 & 10.00 & Contributes to permanent learning & 2 & 3.08 \\
\hline Directs teachers to research & 1 & 1.67 & & & \\
\hline $\begin{array}{l}\text { Can't produce creative solutions for } \\
\text { everyday life }\end{array}$ & 2 & 3.33 & I do not know & 8 & 12.31 \\
\hline
\end{tabular}


Table 6 Respondents' opinions about the limitations of STEM approach

\begin{tabular}{|c|c|c|c|c|c|}
\hline Preschool teachers (60 people) & & & Preschool teacher candidates (65 people) & & \\
\hline $\begin{array}{l}\text { People who will implement this approach need } \\
\text { to be trained (in-service training) }\end{array}$ & 17 & 28.33 & $\begin{array}{l}\text { People who will implement this approach need } \\
\text { to be trained (in-service training) }\end{array}$ & 15 & 23.08 \\
\hline $\begin{array}{l}\text { Failure to take steps regarding this approach in } \\
\text { the education system }\end{array}$ & 11 & 18.33 & $\begin{array}{l}\text { Failure to take steps regarding this approach in } \\
\text { the education system }\end{array}$ & 1 & 1.54 \\
\hline Time problem & 10 & 16.67 & Time problem & 14 & 21.54 \\
\hline It is directed to a limited area & 6 & 10.00 & Requires preparation & 3 & 4.62 \\
\hline Excessive class size may cause problems & 6 & 10.00 & Excessive class size may cause problems & 4 & 6.15 \\
\hline Small age of children & 4 & 6.67 & $\begin{array}{l}\text { Must be appropriate for children's cognitive } \\
\text { development }\end{array}$ & 9 & 13.85 \\
\hline It can be difficult to adapt to any activities & 4 & 6.67 & Being foreign to produce something & 1 & 1.54 \\
\hline $\begin{array}{l}\text { Activities should not be carried out in different } \\
\text { areas }\end{array}$ & 1 & 1.67 & & & \\
\hline No idea & 3 & 5.00 & No idea & 20 & 30.77 \\
\hline
\end{tabular}

According to Table 5, the participants stated the benefits of the STEM approach as developing different thinking skills, supporting children's cognitive development and creativity, providing an active learning environment, increasing the interest in the course, learning to produce, etc. A few of the preschool teachers stated negative opinions and a little of the teacher candidates have no information about the STEM.

In Table 6 , the participants stated the limitations of the STEM approach to implementing it in the classroom. The majority of the participants complained about the

lack of necessary tools and infrastructure and in-service training for the teachers and the teacher candidates. While the preschool teachers stated the failure to take steps regarding the STEM approach in the education system more than the teacher candidates, the teacher candidates talked more about the time problem. However, in both groups, excessive class size and the young age of children may cause some problems. Moreover, $30.77 \%$ of the teacher candidates have no idea about the limitations of the STEM approach.

According to Table 7, some of the participants from

Table 7 Respondents' opinions about the applicability of STEM approach in the current educational system

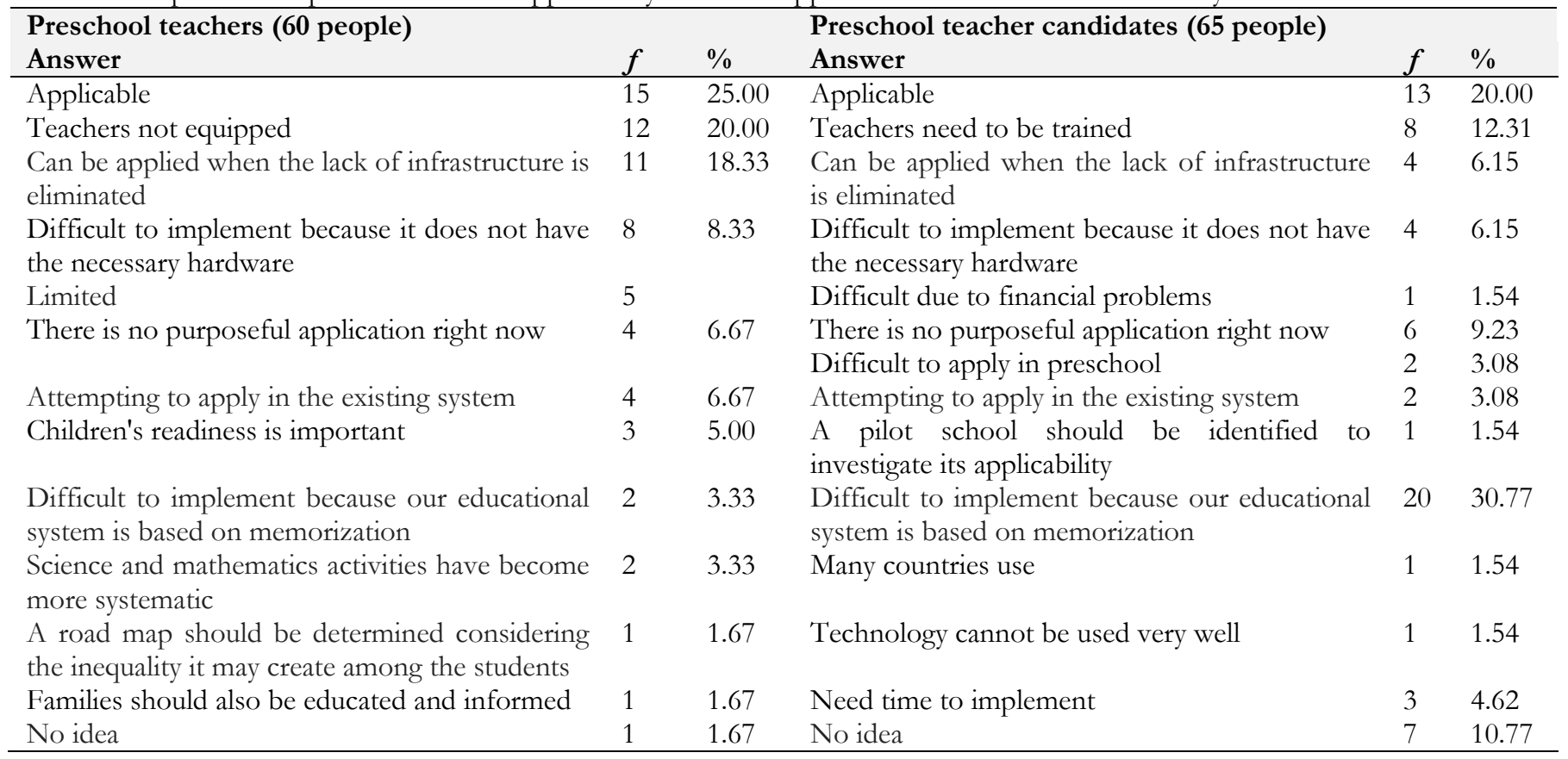


Table 8 Respondents' opinions about the requirements for the successful implementation of STEM approach

\begin{tabular}{|c|c|c|c|c|c|}
\hline Preschool teachers (60 people) & & & Preschool teacher candidates (65 people) & & \\
\hline Answer & $f$ & $\%$ & Answer & $f$ & $\%$ \\
\hline $\begin{array}{l}\text { Infrastructure support should be provided, } \\
\text { equipment should be sufficient }\end{array}$ & 37 & 61.67 & $\begin{array}{l}\text { Infrastructure support should be provided, } \\
\text { equipment should be sufficient }\end{array}$ & 25 & 38.46 \\
\hline In-service training for teachers & 34 & 56.67 & Training for teachers and teacher candidates & 30 & 46.15 \\
\hline $\begin{array}{l}\text { The students should be interested in studies, } \\
\text { develop their thinking skills should be given } \\
\text { weight, should be given the opportunity to make } \\
\text { production }\end{array}$ & 13 & 21.67 & $\begin{array}{l}\text { The students should be interested in studies, } \\
\text { develop their thinking skills should be given } \\
\text { weight, should be given the opportunity to } \\
\text { make production }\end{array}$ & 5 & 7.69 \\
\hline Families should be informed & 10 & 16.67 & Families should be informed & 2 & 3.08 \\
\hline $\begin{array}{l}\text { The education system should be designed } \\
\text { accordingly }\end{array}$ & 6 & 10.00 & $\begin{array}{l}\text { The education system should be designed } \\
\text { accordingly }\end{array}$ & 16 & 24.62 \\
\hline Teachers need to be open to innovation & 5 & 8.33 & Teachers need to be open to innovation & 2 & 3.08 \\
\hline $\begin{array}{l}\text { Students' readiness should be taken into } \\
\text { consideration }\end{array}$ & 4 & 6.67 & $\begin{array}{l}\text { Students' readiness should be taken into } \\
\text { consideration }\end{array}$ & 4 & 6.15 \\
\hline $\begin{array}{l}\text { The socioeconomic level of families should be } \\
\text { considered }\end{array}$ & 3 & 5.00 & STEM approach can be applied if simplified & 1 & 1.54 \\
\hline $\begin{array}{l}\text { Technology must be used correctly and } \\
\text { effectively }\end{array}$ & 2 & 3.33 & $\begin{array}{l}\text { Technology must be used correctly and } \\
\text { effectively }\end{array}$ & 1 & 1.54 \\
\hline Teamwork required & 2 & 3.33 & Teamwork required & 1 & 1.54 \\
\hline & & & Class size must be low & 2 & 3.08 \\
\hline STEM courses should be added to universities & 2 & 3.33 & $\begin{array}{l}\text { STEM courses should be added to } \\
\text { universities }\end{array}$ & 2 & 3.08 \\
\hline Needs time to implement & 2 & 3.33 & Needs time to implement & 2 & 3.08 \\
\hline & & & Discipline, order & 1 & 1.54 \\
\hline STEM centers should be established & 1 & 1.67 & More science centers should be opened & 2 & 3.08 \\
\hline No idea & 4 & 6.67 & No idea & 11 & 16.92 \\
\hline
\end{tabular}

both groups think that the STEM approach can apply in the current educational system. On the other hand, teachers who will implement STEM in their classes not trained, the infrastructure of the schools is still a big problem; there are some financial problems, etc. A high percentage of the teacher candidates think that the educational system in Turkey, unfortunately, based on the memorization of some facts, theories, and knowledge, so it is challenging to implement STEM in the existing circumstances.

In Table 8, the answers to the requirements for the successful implementation of the STEM approach shown. While the preschool teachers pay attention to the infrastructure and equipment support at the first level, the teacher candidates pay attention to training for teachers and teacher candidates. Nevertheless, the majority of both groups talked about the same requirements in the first two levels but in different percentages. However, the participants think that students should allow making a product and so develop their thinking skills. Furthermore, the participants believe that the education system in Turkey should design according to the STEM approach.

\subsection{Discussion}

In the research, the views of the preschool teachers and preschool teacher candidates about the applicability of the STEM approach taken through the screening form. The answers of the participants shown in tables in the findings section. If the tables in the findings analyzed in detail, it seen that the responses of both groups can discuss under three main themes; (1) The effects of the STEM approach, (2) The applicability of the STEM approach in preschool education, and (3) The requirements of the applicability of the STEM approach in Turkish educational system.

The effects of the STEM approach

The vast majority of the participants mentioned the positive effects of the STEM approach. While they are defining the STEM approach, they said that it is an approach in which theoretical knowledge turned into practice. Then, they explained it as the STEM approach provides an active learning environment, and children learn by having fun in cooperation. Moreover, some of the participants said that the STEM approach enables the active participation of children. STEM-based activities help students make sense of the information and make it more permanent as it transfers information to students through a life (Wang, 2012). Because of these, a considerable percentage of the participants think that the STEM approach by concretizing learning provides better and lasting education. Also, students who receive STEM education will learn better, and their motivation will increase (Hiğde, 2018). Studies are showing that there is a positive effect on motivation and learning strategies in STEM applications (Green, 2012; Kang, Ju, \& Jang, 2013; Kong \& In-Cheol, 2014). 
As seen in the tables, some participants declared that the STEM approach gives students more positive attitudes towards science courses as well as the students gain $21^{\text {st-century skills by the STEM approach. It requires }}$ the use of new applications such as science education applications and engineering design activities that will enable students to have these stated competencies as Fortus, Dershimer, Krajcik, Marx, \& Mamlok-Naaman (2004) claimed in their research.

The participants stated that the STEM approach gives children different thinking abilities. They thought that the approach is a realistic, collaborative, and problem-based approach. When the studies in the literature examined, it seen that the STEM approach improves the students' high-level thinking skills, provides real-life applications by less fragmenting the learning process, gives the students the opportunity for learning transfer, improves the motivation of the students and improves the knowledge of the subject with more than one perspective (Ellis \& Fouts, 2001). In addition to the development of knowledge and skills of the cognitive dimension, it seems that the increase of motivation in the emotional field is an essential factor in the success of the students (Thompson \& Mintzes, 2002). Thus, some of the participants mentioned about developing self-confidence and improving social intelligence by the STEM approach.

In addition, the participants stated that the STEM approach supports children to produce unique products. Student products enable students to make sense of information in a way that facilitates the cognitive processes needed by the learner to form their understanding (Liu \& Chen, 2010). Furthermore, the STEM approach enables students to develop curiosity, creativity, and problem-solving skills similar to the researches in the literature (Barak \& Doppelt, 2000; Doppelt \& Barak, 2002; Doppelt, 2005; 2009). Hacıŏlu (2017) found similar findings in her research. She found that students' creativity and problem-solving skills developed at the end of the experimental process, which the STEM approach used as the instructional technique. These results can explain by the fact that the design process, which is a problem-solving process and the creative thinking process and engineering design process, contain similar steps (Doppelt, 2009).

Additionally, some preschool teachers and teacher candidates said that using the STEM approach in schools keeps the country advanced in science and technology. As Lacey \& Wright (2009) stated in their study, from this point of view, when STEM education considers, a country's leadership in technological and scientific innovations and economic development is related to integrating this approach into the education system. STEM education and training expected to provide the country with three key intellectual gains (National Science Teachers Association [NSTA] 2008): (1) It helps to educate scientists and engineers who continue research and development at the heart of the country's economic growth, (2) It enables technologically competent employees to keep up with rapidly developing scientific and engineering innovations, (3) Contributes to the upbringing of scientific literate voters and citizens who make intelligent decisions about public policy and understand the world around them.

The applicability of the STEM approach in preschool education

A vast majority of the participants think that the STEM approach can be applicable in preschool education. Some of them stated that the STEM activities support all development areas of children, such as curiosity, creativity, cognitive development, and different perspectives. Besides, children can actively participate in the lessons, and they can produce unique and innovative products through STEM activities. In this way, children develop a positive attitude towards mathematics, science, technology, and engineering. According to Bagiati and Evangelou (2015), early years has been seen as the perfect moment to start engineering education. Moreover, being interested in engineering in Early Childhood Education could increase the interest in STEM career fields (Dejarnette, 2012).

Because children can actively participate in the STEM activities and STEM activities can make embody abstract concepts, children learn to make sense of their world gaining a complete and more substantial understanding through hands-on and open-ended play experiences, which are a vital component in STEM education (Nell, Drew, \& Bush, 2013). Torres-Crespo, Kraatz, \& Pallansch (2014) believe that play is essential in the early years because it motives children's development, and it can understand as the children's self-sense cognitive processes, socialization, and physical coordination.

Furthermore, some participants think that if children learn something through STEM activities, their lives will be more comfortable in the future. Contrarily, some have made it clear that they do not support STEM, while others have given some reasons, such as requiring a lot of preliminary work and research, being harmful technology for preschool children. Some of the preschool teachers complained about the changing of the national educational system by the effect of governmental policies. Thus, they do not support the STEM approach or another new educational technique, methods, etc.

According to Sparkes (2017), in STEM applications, students ask questions from a critical point of view. In this respect, they examine the problem, produce solutions to problems with original thoughts, are productive, collaborate, and communicate in group work. These applications support one's scientific thinking, imagination, self-expression, and self-confidence. Also, Öcal (2018) found the same results. Öcal (2018) tried to reveal the 
effect of the Early STEM Educational Program on science process skills of 60-66 months children, and she found that the Early STEM Educational Program had been more successful in developing science process skills and permanency of it.

As seen in the findings, some of the participants said that the STEM approach is not viable in preschool. The debate between people who are thinking it is viable and are assuming the opposite continues. Some researchers believe that to participate in a STEM activity, and students should have some root information (Öcal, 2018). There are still questions of children's developmental readiness for the acquisition of engineering concepts and practices are of primary concern (Bagiati \& Evangelou, 2015). But actually, there is a group of researchers who think that it is not true because children are engineers, behave as a scientist naturally. STEM experiences can support children's brain development and literacy development (Stone-MacDonald, Bartolini, Douglass, \&, 2012; Torres-Crespo, Kraatz, \& Pallansch., 2014).

The requirements of the applicability of the STEM approach in the Turkish educational system

As seen in the tables of findings, participants give extra attention to whom the implementers of the STEMbased activities; in other words, teachers and teacher candidates. The majority of them stated that teacher and teacher candidates should train for the STEM approach. Öner (2017) explained that teachers are essential in the proper implementation and promotion of STEM applications because teachers are useful in establishing and implementing the STEM curriculum, creating formal learning environments, selecting education and training methods, and introducing STEM to management and society. Moreover, some of the participants wanted some STEM-based courses to add to the university program for teacher candidates. Many studies have shown that training for teachers to use the multidisciplinary approach given during their university years is useful (Stohlmann, Moore, \& Roehrig, 2012). For this reason, preschool teachers should have elective or compulsory courses in science, mathematics, engineering, and technology before graduation. Following these courses, training should provide on how to bring these disciplines together and how to reduce them to children's levels. As seen in the findings, Öcal (2018) suggested that graduated teachers can give in-service training. In this way, teachers' selfefficacy in STEM fields can be increased (Öcal, 2018). Caprara, Barbaranelli, Steca, \& Malone (2006) stated that teachers who think that their self-efficacy have increased are effective in improving students' school success. For this reason, it is essential that teachers train in STEM fields and that teachers' competence in these fields increases.

However, preschool teachers and teacher candidates trained for the STEM approach, schools in Turkey are not appropriate in terms of infrastructure lacking for implementing it. The vast majority of the participants complained about that issue. Uğraş (2017) found a similar result in his research. But Akgündüz, et al. (2015) stated in their STEM report the financial support could give by the government and taken via projects. The US government and some other countries afford a considerable amount of money for establishing a system based on the STEM approach. In Turkey, the STEM approach is a necessity as Akgündüz, et al. (2015) declared in their Turkey STEM report. The number of science centers and museums can increase; STEM centers can found. And some financial aid can be taken by industrial cooperation. Actually, in preschool to implement the STEM approach does not require too much infrastructure and equipment because too many equipment from daily life can use in STEMbased activities. For preschool students, using daily life materials can be better for their imaginations' development. According to Torres-Crespo, Kraatz, \& Pallansch (2014), it is the preschool teachers' responsibility to understand that it is the most important of the early years, and to prepare cheerful, constructive, practical and play-based activities that enable children to learn all the necessary skills that will allow them to thrive in school and life.

Another necessity for implementing the STEM approach in Turkey preschool classes, families should be informed as the participants stated in our research. Similarly, Uğraş (2017), Uyanık Balat \& Günşen (2017) talk about three essential factors in providing STEM skills to preschool children. These are education programs, teacher training, and family. Yllmaz (2017) found that there was a significant difference in favor of the post-test in terms of estimation, inference, and scientific communication skills for experimental group students in the study, where the effects of family participation science activities on science process skills and attitudes towards the science of 5-6-year-old children. In the preschool period, family involvement is a very advantageous condition. Torres-Crespo, Kraatz, \& Pallansch (2014) stated in their reports when the parents are engaged in the activities, their children become more successful, regardless of race, parental education, or socioeconomic status (NSTA, 2008).

\section{CONCLUSION}

In this research, the questions asked to the preschool teachers and preschool teacher candidates and their answers are focused on the effects of the STEM approach, the applicability of the STEM approach in preschool education and finally the requirements of the applicability of the STEM approach in Turkish educational system and therefore the discussion carried out in this format. 


\section{REFERENCES}

Aldemir, J., \& Kermani, H. (2017). Integrated STEM curriculum: Improving educational outcomes for head start children. Early Child Development and Care, 187(11), 1694-1706.

Akgündüz, D., \& Akpınar, B. C. (2018). Okul öncesi eğitiminde fen eğitimi temelinde gerçekleştirilen STEM uygulamalarının öğrenci, öğretmen ve veli açısından değerlendirilmesi. Yaşadıkşa Eğitim Dergisi, 32(1), 1-26.

Akgündüz, D., Aydeniz, M., Çakmakçı, G., Çavaş, B., Çorlu, M. S., Öner, T., \& Özdemir, S. (2015). STEM eğitimi Türkiye raporu. Istanbul: Scala Basim.

Atiles, J. T., Jones, J. L., \& Anderson, J. A. (2013). More than a readaloud: Preparing and inspiring early childhood teachers to develop our future scientists. Teacher Education and Practice, 26(2), 285-300.

Balc1, A. (2011). Araştırma Sosyal Bilimlerde Araștırma (Gözden geçirilmis ve geliștirilmiş 9. bask1). Ankara: PegemA Yaynculık.

Bagiati, A., \& Evangelou, D. (2015). Engineering curriculum in the preschool classroom: the teacher's experience. European Early Childhood Education Research Journal, 23(1), 112-128.

Barak, M., \& Doppelt, Y. (2000). Using portfolios to enhance creative thinking. Journal of Technology Studies, 26(2), 16-25.

Büyüköztürk, Ş., Çakmak, E. K., Akgün, Ö. E., Karadeniz, Ş., \& Demirel, F. (2012). Bilimsel Araștırma Yöntemleri, Geliștirilmiş 11. Basker, s, 249

Campbell, C., Speldewinde, C., Howitt, C., \& MacDonald, A. (2018). STEM practice in the early years. Creative Education Journal Special Edition Preschool Education Research, 9(1), 11-25.

Caprara, G. V., Barbaranelli, C., Steca, P., \& Malone, P. S. (2006). Teachers' self-efficacy beliefs as determinants of job satisfaction and students' academic achievement: A study at the school level. Journal of school psychology, 44(6), 473-490.

Catherwood, D. (2000). New views on the young brain: offerings from developmental psychology to early childhood education. Contemporary Issues in Early Childhood, 1(1), 23-35.

Chesloff, J. D. (2013). STEM education must start in early childhood. Education Week, 32(23), 27-32.

Clements, D. H., Sarama, J., \& DiBiase, A. M. (2002). Preschool and Kindergarten Mathematics: a national conference. (Early Childhood Corner). Teaching Children Mathematics, 8(9), 510-515.

Cohen, L., and Manion, L. (1989). Research Methods in Education. 4th ed. New York: Routledge.

DeJarnette, N. (2012). America's children: Providing early exposure to STEM (science, technology, engineering and math) initiatives. Education, 133(1), 77-84.

DiPerna, J. C., Lei, P. W., \& Reid, E. E. (2007). Kindergarten predictors of mathematical growth in the primary grades: An investigation using the Early Childhood Longitudinal Study-Kindergarten cohort. Journal of Educational Psychology, 99(2), 369.

Doppelt, Y. (2005). Assessment of project-based learning in a mechatronics context. Journal of Technology Education, 16(2), 7-24.

Doppelt, Y. (2009). Assessing creative thinking in design-based learning. International Journal of Technology and Design Education, 19(1), 55-65.

Doppelt, Y., \& Barak, M. (2002). Pupils Identify Key Aspects and Outcomes of a Technological Learning Environment. Journal of Technology Studies, 28(1), 22-28.

Drew, C. J., Hardman, M. L., and Hart, A. W. (1996). Designing and Conducting Research: Inquiry in Education and Social Science. 2nd ed. Boston: Allyn and Bacon.

Ekiz, D. (2009). Bilimsel Araștrma Yöntemleri (9. baski) Scientific Research Methods (9th ed.). Ankara: Anı Yayıncilik.

Ellis, A. K., \& Fouts, J. T. (2001). Interdisciplinary curriculum: The research base.

Fortus, D., Dershimer, R. C., Krajcik, J., Marx, R. W., \& MamlokNaaman, R. (2004). Design-based science and student learning. Journal of Research in Science Teaching, 41(10), 1081-1110.
Green, A. (2012). The integration of engineering design projects into the secondary science classroom. (Thesis). Michigan State University.

Hacioğlu, Y. (2017). The effect of science, technology, engineering and mathematics (STEM) education based activities on prospective science teachers' critical and creative thinking skills. (Dissertation)., Gazi University.

Hayes, N. (2007). Perspectives on the relationship between education and care in early childhood: A research paper. Dublin: National Council for Curriculum and Assessment (NCCA). Accessed https://www.curriculumonline.ie/getmedia/f9fda0a5-bf83-4e769588-44ef32b6015e/ECSEC05 Exec1_Eng.pdf

Hayes, N. (2008). Teaching matters in early educational practice: The case for a nurturing pedagogy. Early Education and Development, 19(3), 430-440.

Hiğde, E. (2018). The Investigation of the effect of the STEM activities prepared for 7 th class students in terms of different variables. (Dissertation), Adnan Menderes University.

Kang, J., Ju, E. J., \& Jang, S. (2013). The Effect of Science-based STEAM Program using a Portfolio on Elementary Students' Formation of Science Concepts. Journal of Korean Elementary Science Education, 32(4), 593-606.

Kong, Y. T., \& In-Cheol, J. (2014). The effect of subject based STEAM activity programs on scientific attitude, self efficacy, and motivation for scientific learning. International Information Institute (Tokyo). Information, 17(8), 3629 .

Lacey, T. A., \& Wright, B. (2009). Employment outlook: 2008-18occupational employment projections to 2018. Monthly Lab. Rev., $132,82$.

Liu, C. C., \& Chen, I. J. (2010). Evolution of constructivism. Contemporary issues in education research, 3(4), 63-66.

Miles, M. B., \& Huberman, A. M. (1994). Qualitative Data Analysis. 2nd ed. California: Sage Publications, Inc.

National Science Teachers Association (NSTA). (2008). STEM education for student. Corporate Success, 20(3), 23.

Nell, M., Drew, W., \& Bush, D. (2013). From play to practice: Connecting teachers' play to children's learning. Washington, DC: NAEYC.

Öcal, S. (2018). Examining the effects of early STEM educational program on the scientific process skills of preschool children between 60-66 months. Master diss. Yıldız Technical University.

Öner, A. T. (2017). STEM-FeTeMM okulları. STEM-fen, teknoloji, mühendislik, ve matematik eğitimi: Kuram ve uygulamalar ( $p p . x x-x x$ ). Istanbul. Pusula: 27-36.

Ozkan, G., \& Topsakal, U. U. (2017). Examining students' opinions about STEAM activities. Journal of Education and Training Studies, $5(9), 115-123$

Stohlmann, M., Moore, T. J., \& Roehrig, G. H. (2012). Considerations for teaching integrated STEM education. Journal of Pre-College Engineering Education Research (J-PEER), 2(1), 4.

Sparkes, V. P. (2017). STEAM nedir. İstanbul: Ayrntı Yaynlar.

Stone-MacDonald, A., Bartolini, V., Douglass, A., \& Love, M. (2012). Focusing a new lens: STEM professional development for early education and care educators and programs. Accessed: https://www.communityinclusion.org/ecs/ecs/stem/FocusingN ewLensFINALfullreport.pdf

Thompson, T. L., \& Mintzes, J. J. (2002). Cognitive structure and the affective domain: on knowing and feeling in biology. International Journal of Science Education, 24(6), 645-660.

Torres-Crespo, M. N., Kraatz, E., \& Pallansch, L. (2014). From Fearing STEM to Playing with It: The Natural Integration of STEM into the Preschool Classroom. SRATE Journal, 23(2), 8-16.

Uğraş, M. (2017). Okul öncesi öğretmenlerinin STEM uygulamalarına yönelik görüşleri. Eğitimde Yeni Yaklaşımlar Dergisi, 1(1), 39-54.

Uyanık Balat, G., \& Günşen, G. (2017). STEM approach in pre-school period. The Journal of Academic Social Science, 5(42), 337-348.

Wang, H.H. (2012). A new era of science education: Science teachers' perceptions and classroom practices of science, technology, engineering, and mathematics (STEM) integration. (Dissertation). University of Minnesota. 
Yıldırım, A., \& Şimşek, H. (2005). Qualitative research methods in social sciences. Ankara: Seçkin Publishing.

Yildirim, B. (2016). An Analyses and Meta-Synthesis of Research on STEM Education. Journal of Education and Practice, 7(34), 23-33.

Yilmaz, G. (2017). The affect of science experiments with family involvement to 5-6 age group of children' science process skills and their attitudes to science. (Dissertation). Uludağ University. 